\title{
Pathological investigation of neuroprotective activity of new derivatives of fused pyrazolyl-thienopyridines in Corazol-induced seizures
}

\author{
H.V. Gasparyan, S.A. Buloyan, A.E. Pogosyan, L.M. Arshakyan, L.S. Harutyunyan, \\ R.G. Paronikyan, I.M. Nazaryan, Sh.Sh. Dashyan, E.G. Paronikyan
}

Scientific Technological Center of Organic and Pharmaceutical Chemistry National Academy of Sciences of the Republic of Armenia, Yerevan, Armenia

Introduction. Seizures provoke several morphological alterations in the brain structures. These alterations are primarily located in the hippocampal CA1 region and the entorhinal cortex. Recurrent seizures are common in patients with epilepsy. Therapeutic options for this disease are very limited and most of them are aimed at relieving symptoms. In most cases, to treat epilepsy, anti-seizure drugs are used. Nevertheless, one-third of affected individuals have resistance to them. Thus, the study of new effective agents that can prevent epileptogenesis is still an ongoing challenge. In this work, we aimed to study the neuroprotective activity of several new derivatives of tricyclic pyrazolyl substituted thieno[2,3-c]isoquinolins (SHD-89 and SHD-91) and pyrano[4,3-d]thieno[2,3-b]pyridines (SHD-78 and SHD-85) as potential anti-seizure drugs.

Materials and methods. The study was performed on mice $(\mathrm{n}=60)$. The action of compounds SHD-78, SHD-85, SHD-89, and SHD-91 was tested in seizures with and without Corazol administration. Histopathological examinations were performed in the hippocampus and the entorhinal cortex in different experimental groups. Results. The study showed that under the action of SHD-89 and SHD-78, there was a reduction in the number of neurons and activation of glial cells in examined regions of the brain. SHD-91 caused severe neurodegenerative effects with changes in the brain structure. In contrast, under the action of SHD-85, the number of neurons was higher and with lower activation of glial cells.

Conclusion. Studies showed that among the tested compounds SHD-85 possessed moderate neuroprotective activity and reduced gliosis and neuronal loss induced by Corazol.

Keywords: anti-seizure drugs, pyrazolylthienopyridines, hippocampus, entorhinal cortex, histopathological examination

Corresponding author: Hrachik V. Gasparyan. E-mail: hrachikgasparyan@mail.ru

For citation: Gasparyan H.V., Buloyan S.A., Pogosyan A.E., Arshakyan L.M., Harutyunyan L.S, Paronikyan R.G., Nazaryan I.M., Dashyan Sh.Sh., Paronikyan E.G. Pathomorphological investigation of neuroprotective activity of new derivatives of fused pyrazolyl-thienopyridines in Corazol-induced seizures. Clin. exp. morphology. 2021;10(4):53-62. DOI: 10.31088/CEM2021.10.4.53-62.

Funding. The study was supported by the RA MES State Committee of Science, Project No. 18T-1D066.

Conflict of interest. The authors declare no conflict of interest.

Received 30.08.2021. Received in revised form 15.09.2021. Accepted 22.09.2021.

УДК 615.213, 611.018.8, 616-018

Патоморфологическое исследование нейропротекторной активности новых производных
конденсированных пиразолил-тиенопиридинов при судорогах, индуцированных коразолом Г.В. Гаспарян, С.А. Булоян, А.Е. Погосян, Л.М. Ариакян, Л.С. Арутюнян, Р.Г. Пароникян, И.М. Назарян, Ш.Ш. Дашян, Е.Г. Пароникян

Научно-технологический центр органической и фармацевтической химии Национальной академии наук Республики Армения, Ереван, Армения

Введение. Судороги вызывают несколько морфологических изменений в структуре мозга. Эти изменения в основном локализуются в области СА1 гиппокампа и в энторинальной коре. Рецидивирующие судороги часто встречаются у пациентов с эпилепсией. Варианты лечения этого заболевания очень 
ограничены, и большинство из них нацелено на облегчение его симптомов. Во многих случаях для терапии эпилепсии используют противосудорожные препараты. Тем не менее одна треть пациентов с этим состоянием резистентна к противосудорожным препаратам. Таким образом, изучение новых эффективных агентов, которые могут предотвратить эпилептогенез или предотвратить судороги, попрежнему остается сложной задачей в медицине. В данной работе мы изучили нейропротекторную и противосудорожную активность нескольких новых производных трициклических пиразолилзамещенных тиено[2,3-с]изохинолинов (SHD-89 и SHD-91) и пирано[4,3-d]тиено[2,3-b]пиридинов (SHD-78 и SHD-85) в качестве потенциальных противосудорожных препаратов.

Maтериаль и методы. Исследования проводились на белых беспородных мышах. Действие этих соединений (SHD-89, SHD-91, SHD-78, SHD-85) было протестировано при судорогах, вызванных коразолом, а также без действия хемоконвульсанта. Гистопатологические исследования проведены в гиппокампе и энторинальной коре головного мозга, в разных экспериментальных группах.

Результаты. Исследования показали, что под действием SHD-89 и SHD-78 происходят уменьшение количества нейронов и активация глиальных клеток в исследуемых областях мозга, тогда как соединение SHD-91 оказывает тяжелые нейродегенеративные эффекты на мозговую ткань, с изменением структуры мозга. Напротив, под действием SHD-85 количество нейронов было выше по сравнению с этим показателем в других экспериментальных группах, с меньшей активацией глиальных клеток. Заключение. Исследования показали, что среди всех изученных соединений (SHD-89, SHD-91, SHD-78, SHD-85) SHD-85 обладает умеренной нейропротекторной активностью и предотвращает глиоз и потерю нейронов, вызванную коразолом.

Ключевые слова: противосудорожные препараты, пиразолилтиенопиридины, гиппокамп, энторинальная кора, гистопатологическое исследование

Для корреспонденции: Грачик Ваграмович Гаспарян. E-mail: hrachikgasparyan@mail.ru

Для цитирования: Гаспарян Г.В., Булоян С.А., Погосян А.Е., Аршакян Л.М., Арутюнян Л.С., Пароникян Р.Г., Назарян И.М., Дашян Ш.Ш., Пароникян Е.Г. Патоморфологическое исследование нейропротекторной активности новых производных конденсированных пиразолил-тиенопиридинов при судорогах, индуцированных коразолом. Клин. эксп. морфология. 2021;10(4):53-62 (англ.). DOI: 10.31088/CEM2021.10.4.53-62.

Финансирование. Исследование выполнено при финансовой поддержке Государственного комитета науки МОН РА в рамках исследовательского проекта № 18T-1D066.

Конфликт интересов. Авторы заявляют об отсутствии конфликта интересов.

Статья поступила 30.08.2021. Получена после рецензирования 15.09.2021. Принята в печать 22.09 .2021$.

\section{Introduction}

Seizure is a paroxysmal alteration of brain function caused by hypersynchronous discharges of CNS neurons. Seizures are divided into three categories: generalized, fo$\mathrm{cal}$, and status epilepticus (SE) [1]. Epilepsy is one of the most common neurological disorders that includes a number of different syndromes and is characterized by recurrent unprovoked seizures [2].

Studies on different animal models of epilepsy and the human brain with temporal lobe epilepsy (TLE) showed that epileptic seizures induced neuronal loss of pyramidal cells of the hippocampal CA1 region and reorganization of the granular cells of the dentate gyrus that was accompanied by astrocytic hypertrophy and proliferation $[3,4]$. Moreover, patients with mesial TLE show histopathological alterations in the entorhinal cortex and amygdala, which accompany extensive gliosis $[5,6]$.

Therapeutic options for seizure syndrome are very limited and most of them are aimed at relieving its symptoms rather than preventing epileptogenesis [7]. The main treatment for epilepsy is still considered to be anti-seizure drugs (ASDs), yet at least one-third of affected individuals continue to experience spontaneous recurrent seizures.
These patients not only have continuous seizure activity but are also at risk of developing cognitive impairment and comorbid mental health problems [8]. Thus, a new effective agent that can prevent epileptogenesis or cure convulsions during any type of seizures with mild side effects is still an ongoing challenge. For the same reason, it is very important to search for original drugs in new series of chemical compounds, in particular, among the derivatives of new heterocyclic systems.

A number of heterocyclic derivatives containing nitrogen atoms serve as universal structural units for the synthesis of complex heterocyclic systems. Pyridine is the parent ring system of a large number of naturally occurring products and important pharmaceuticals. The derivatives of condensed pyridines are of interest as biologically active substances. Thus, alkaloids of the pyrano[3,4-c]pyridine series extracted from plants exert various effects: hypotensive, anticonvulsant, antipsychotic, anti-inflammatory, and hypothermic [9]. Furthermore, pyrano[3,4-c]pyridine derivatives are the starting compounds for the synthesis of indole alkaloids, in particular, camptothecin exhibiting antitumor activity $[10,11]$. The pyrazole nucleus attracted great attention due to the use of this ring system as an 
important core structure in many drug substances. A large number of substituted pyrazolopyridine derivatives were found to possess diverse biological properties, such as antimicrobial [12, 13], antiviral [14], antileishmanial [15], and anti-inflammatory [16] non-anionic antiplatelet agents [17], as well as psychotropic effects [18].

This study continues our research on the synthesis and evaluation of the neurotropic activity of fused heterocyclic systems containing nitrogen atoms $[19,20]$. New derivatives of tricyclic pyrazolyl substituted thieno[2,3-c] isoquinolins (SHD-89 and SHD-91) and pyrano[4,3-d] thieno[2,3-b]pyridines (SHD-78 and SHD-85) were synthesized in the Laboratory of the synthesis of psychotropic compounds. In this work, we aimed to study their neuroprotective activity in Corazol-induced seizure models as potential ASDs.

\section{Materials and methods}

Chemical compounds. We studied anticonvulsant and neuroprotective properties of the following compounds:

- SHD-89: thieno[2,3-c]isoquinolin-1-amine-N-phenyl

- SHD-78: pyrano[4,3-d]thieno[2,3-b]pyridin-1-amine$\mathrm{N}$-phenethyl

- SHD-91: thieno[2,3-c]isoquinolin-1-amine- N-(2,4dimethoxyphenyl)

- SHD-85: pyrano[4,3-d]thieno[2,3-b]pyridin-1-amine$\mathrm{N}-(3,4-$ dichlorophenyl)

Design of a Corazol-induced animal model. For histopathological evaluation of the brain tissue, we conducted experiments on 60 male and female mice weighing 18-24 g. All novel compounds were administered via intraperitoneal injection at a $50-\mathrm{mg} / \mathrm{kg}$ dose for 3 successive days. To model the seizures, 1 hour after the injections, all animals from the control group and experimental groups 1, 3, 5, and 7 received the same dose of Corazol via subcutaneous injection.

The animals were divided into 10 groups $(n=6$ in each group):

A. Intact group: normal animals

B. Control group: Corazol-treated group

C. Experimental group 1: treated with Corazol and compound SHD-89

D. Experimental group 2: treated with compound SHD-89

E. Experimental group 3: treated with Corazol and compound SHD-78

F. Experimental group 4: treated with compound SHD-78

G. Experimental group 5: treated with Corazol and compound SHD-91

H. Experimental group 6: treated with compound SHD-91

I. Experimental group 7: treated with Corazol and compound SHD-85

J. Experimental group 8: treated with compound SHD-85 All experiments were performed according to the Directive 2010/63/EU of the European Parliament. The animals were kept in a room at $21 \pm 2^{\circ} \mathrm{C}$ and a 12 -hour light/dark cycle and given ad libitum access to food and water.

Histopathological examination. After day 3 of the experiment, the mice were sacrificed under anesthesia
(40 mg/kg Nembutal Sodium via intraperitoneal injection). Brain tissue was collected and stored in a $10 \%$ neutral buffered formalin. The samples were dehydrated and embedded in paraffin; 3-5- $\mu \mathrm{m}$ microtome sections were prepared. Brain tissues were cut in coronal sections and stained with Nissl stain.

For morphometric analysis, ten samples of the hippocampal CA1 region and entorhinal cortex were photographed at 400× magnification using AmScope MU500 5MP USB2.0 Microscope Digital Camera \& Software (USA). In the CA1 region, we counted normal neurons with a light nucleus. In the entorhinal cortex, we counted neurons of layers II and III, microglial cells, and astrocytes. All cells were counted with ImageJ 1.x software using Cell Counter Plugin. All data were expressed as means \pm SD. Statistical data analysis was performed using IBM SPSS Statistics 22.0.0 software with one-way ANOVA, followed by Bonferroni post hoc test.

\section{Results and discussion}

Although the source of convulsions is located in other brain areas, the literature review showed that in various animal models of epilepsy, such as TLE and Pilocarpine and Kainate treated models, the main pathological changes (e.g., neurolysis and gliosis) were observed in the hippocampus, entorhinal cortex, amygdala, and thalamus $[5,7$, 21-24]. Our observations showed that the main regions which had undergone pathological alterations after Corazol treatment were the hippocampus and entorhinal cortex. Consequently, we made a pathological evaluation of these regions after Corazol-induced seizures and treated them with different newly synthesized compounds to investigate their neuroprotective effects. Corazol had convulsant effects in animal models due to the inhibition of chlorine channels in the GABAA-receptor complex and the impairment of the GABAergic inhibitory mechanisms [25].

Histological and pathological observations showed that the hippocampi of the intact animals had a normal morphological appearance, i.e., they showed no signs of sclerosis, chromatolysis, or shrinkage of neurons. Pyramidal cells in the CA1 region were neatly arranged with clear nuclei and visible nucleoli, and the cytoplasm had a normal distribution of Nissl bodies (Fig. 1A). The average neuron count in the CA1 region was $101.3 \pm 8.96$ cells in the microscopic field (Fig. 2).

Patients with TLE are known to have cornu ammonis (CA) sclerosis as the most common pathological lesion. The lesion is characterized by severe loss of pyramidal neurons and gliosis in the CA1 region, prosubiculum, and CA3 region [26], with both being less severe in the CA3 region. Compared to the hippocampi of the animals in the intact group, the hippocampi of the animals treated with Corazol had prominent chromatolysis of neurons. Neurons were absent in all regions of the hippocampi, and the CA1 region showed sclerosis (Fig. 1B). The count of pyramidal cells drastically decreased compared to that in the intact animals and was $44.7 \pm 2.87$ cells in the microscopic field 


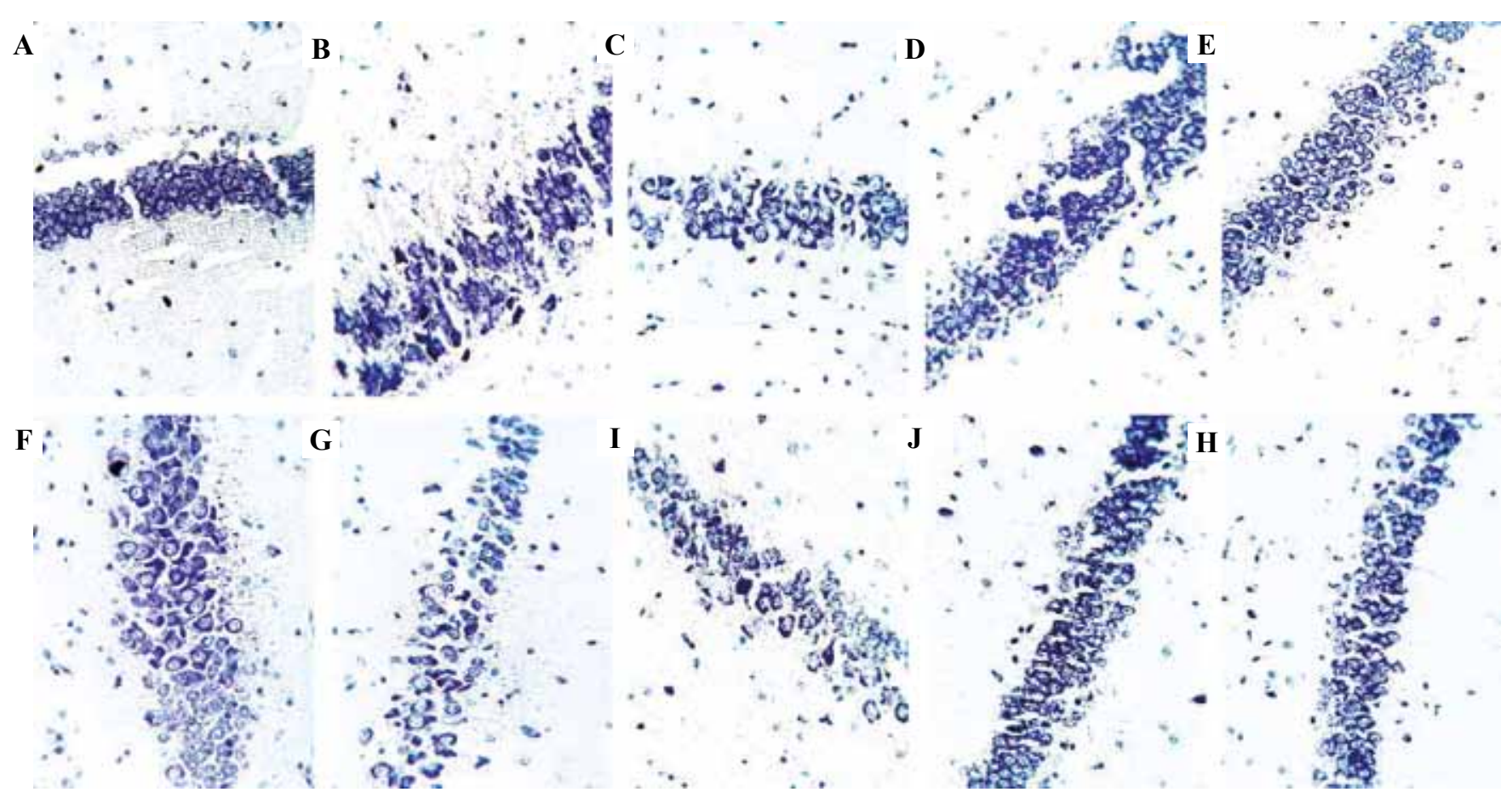

Fig. 1. Photomicrographs of the hippocampus with Nissl stain $\times 400$.

A - intact; B - control animals treated with Corazol; C - animals treated with Corazol and SHD-89; D - animals treated with SHD-89; E - animals treated with Corazol and SHD-78; F - animals treated with SHD-78; G - animals treated with Corazol and SHD-91; H - animals treated with SHD-91; I - animals treated with Corazol and SHD-85; J - animals treated with SHD-85

Puc. 1. Микрофотографии гиппокампа, окрашивание по Нисслю $\times 400$.

A - интактная группа, В - контрольные животные, получавшие коразол, С - животные, получавшие коразол и SHD-89, D - животные, получавшие SHD-89, E - животные, получавшие коразол и SHD-78, F - животные, получавшие SHD-78, $\mathrm{G}$ - животные, получавшие коразол и SHD-91, H - животные, получавшие SHD-91, I - животные, получавшие коразол и SHD-85, J - животные, получавшие SHD-85

(Fig. 2). There was also a prominent activation of astrocytes and microglial cells. In the CA3 region, there was gliosis along with many dark neurons with indistinct nuclei. The vessels near the CA3 region and in the dorsal part of the third ventricle were congested, and the ventricles were collapsed.

In comparison with the hippocampi of the animals in the intact group, those in experimental group 1 showed increased neurodegenerative signs. The number of neurons decreased significantly, especially in the CA1 region (Fig. 1C). Neuron count was $46.6 \pm 4.81$ cells in the microscopic field, which was not statistically different from that of the control group (Fig. 2).

In the hippocampus, there was noticeable activation of microglia. Due to hemodynamic disbalance, delicate vessels of the choroid plexus were disrupted, resulting in the formation of hematoma in the dorsal part of the third ventricle. In addition, there was congestion of the vessels near the $\mathrm{CA} 3$ region. High doses of antiepileptic drugs were shown to cause a high risk of stroke [27]. In experimental models of epilepsy, there were various lesions and changes in the permeability of the blood-brain barrier that is characterized by the leakage of various blood components into the brain [28]. Consequently, in our experiments, intracranial hemorrhages can be due to the high dosage of SHD-89 in a combination with Corazol that leads to changes in the permeability of blood vessels.

In experimental group 2, no noticeable morphological alterations in the hippocampal region were detected. There was a slight activation of astrocytes and hyperchromasia

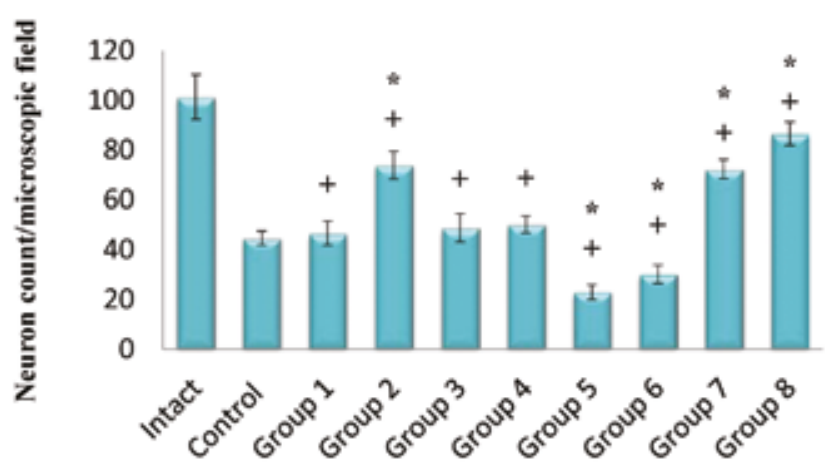

Fig. 2. The count of neuronal cells in the CA1 region. Data are expressed as Mean $\pm \mathrm{SD} ; * \mathrm{p}<0.05$ compared to the control group; $+p<0.05$ compared to the intact group

Puc. 2. Подсчет нейрональных клеток в области СА1. Данные выражены как среднее \pm стандартное отклонение; * $\mathrm{p}<0,05$ по сравнению с контрольной группой; $+\mathrm{p}<0,05$ по сравнению с интактной группой 
of the neurons of the CA3 and CA1 regions. In a higher magnification, the neurons showed darker staining compared to those of the intact animals, but their nuclei were clear with visible nucleoli (Fig. 1D). The pyramidal cell count was $73.9 \pm 5.55$, which is statistically higher compared to that in the control animals [p<0.05] (Fig. 2). These data indicate that compound SHD-89 has a synergic effect on the chemoculvunsant agent.

We observed very similar changes in the hippocampi of animals from experimental group 3. There were hyperchromatic dark neurons and activation of astrocytes. In the CA1 region, the neurons were hyperchromatic and there was chromatolysis of Nissl bodies and microgliosis (Fig. 1E). The neuronal cell count also decreased (48.8 \pm 5.63$)$ and was not statistically different from that in the control animals (Fig. 2).

The blood vessels close to the dentate gyrus were congested. There was noticeable congestion of vessels in the choroid plexus and hemorrhage to the dorsal part of the third ventricle. Along with the above-mentioned morphological changes, there was also atrophy of the medial habenula. Multiple studies have shown that chronic stress induces bilateral atrophy of the medial habenula and the lateral habenula [29]. Thus, the combination of the chemoconvulsant agent and compound SHD-78 result in severe stress response in mice, which leads to the atrophy of this region.

Experimental group 4 showed similar morphological changes: astrogliosis, microgliosis, hyperchromasia of the neurons, and congested blood vessels. In the CA1 region, the number of neurons was reduced and the preserved neurons were mostly chromatolytic. Besides, we observed there few dark pyknotic neurons (Fig. 1F). The neuron count was $50.1 \pm 3.35$ cells in the microscopic field, which was not statistically different from that in the control group (Fig. 2). The congestions in different regions of the brain indicate that compound SHD-78 results in a change in permeability of the blood-brain barrier.

In the brain tissue of animals from experimental group 5, there was a prominent activation and proliferation of astroglia, which resulted in the structural change of the hippocampus, especially in the $\mathrm{CA} 3$ region. The number of pyramidal cells of the CA1 region significantly reduced (Fig. 1G). The neuron count was $23 \pm 3.06$ cells, which was statistically lower compared to that in the control animals (Fig. 2). As a result of structural changes in the hippocampus, the dorsal part of the third ventricle had shrinkage, and delicate vessels of the choroid plexus were disrupted.

Morphological changes in experimental group 6 were almost the same as those in experimental group 5. There was prominent astrogliosis and hyperchromatic dark neurons in the dentate gyrus and CA3 regions. In the CA1 region, there was a reduction in the number of cells and pyknosis (Fig. 1H). The count of pyramidal cells was $30.2 \pm 3.68$, which was also significantly lower compared to that in the control animals (Fig. 2).
The hippocampi of animals from experimental group 6 resembled those of the intact animals. There was mild gliosis, and only a few cells underwent pyknosis and chromatolysis. The number of pyramidal cells of the CA1 region was not visibly reduced, although there was evidence of chromatolysis of Nissl bodies in some nerve cells (Fig. 1I). The count of neurons was $72.3 \pm 3.89$ cells, which was statistically higher compared to that in the control animals but lower than that in the intact animals (Fig. 2).

The animals from experimental group 8 had minor changes in the hippocampal region of the brain as well. The neurons of the CA1 region were mostly neatly arranged with clear nuclei and visible nucleoli, and only few of them had chromatolysis of Nissl bodies (Fig. 1J). There was mild gliosis and a slight reduction in the number of neurons $(86.7 \pm 4.74)$ that was significantly higher than that in the control group but slightly lower than that in the intact group (Fig. 2).

Overall, the animals from experimental group 8 did not show significant pathological changes in the hippocampal region with and without the chemoconvulsant agent.

Another brain region of particular interest involved in epileptic seizures is the entorhinal cortex because it is a part of the hippocampal memory system and constitutes the major gateway between hippocampal formation and the neocortex $[30,31]$. Numerous studies have demonstrated that in patients with TLE, there is atrophy not only of the hippocampus but also of the entorhinal cortex. Additionally, in these patients, quantified significant interactions between the hippocampus and entorhinal cortex were proven to prevent seizure onset [32].

The entorhinal cortex of the normal brain consists of six layers with different types of neurons. Histological observation of the intact brain showed that in layer I of the entorhinal cortex there were few cells, while layer II consisted of islets of round neurons, which were hyperchromatic and had prominent nucleoli (Fig. 3A). The morphometric analysis showed the number of neurons in this layer to be $72.5 \pm 6.22$ cells in the microscopic field (Fig. 4). The cells of this layer project primarily to the dentate gyrus [33].

In layer III, there were medium size pyramidal cells with clear oval nuclei (Fig. 3A). The cells of this layer project predominantly to $\mathrm{CA} 1$ and $\mathrm{CA} 3$ regions [34]. The number of these cells was $32.6 \pm 4.03$ (Fig. 4). Other three layers consist of large pyramidal cells and neurons of different sizes and shapes. In all layers, there was a normal number of glial cells. The morphometric analysis showed the number of microglial cells of the entorhinal cortex to be $9.6 \pm 1.58$ in the microscopic field and that of astrocytes to be $9.6 \pm 1.27$ (Fig. 5).

Astrocytes regulate brain function and are characterized by tight interaction with neurons. In physiological conditions, they play an important role in neuronal metabolism and the synthesis of neurotransmitters. On the other hand, activated reactive astrocytes are characteristic of neurodegenerative diseases. In pathological conditions, astrocytes release several pro-inflammatory mediators, 

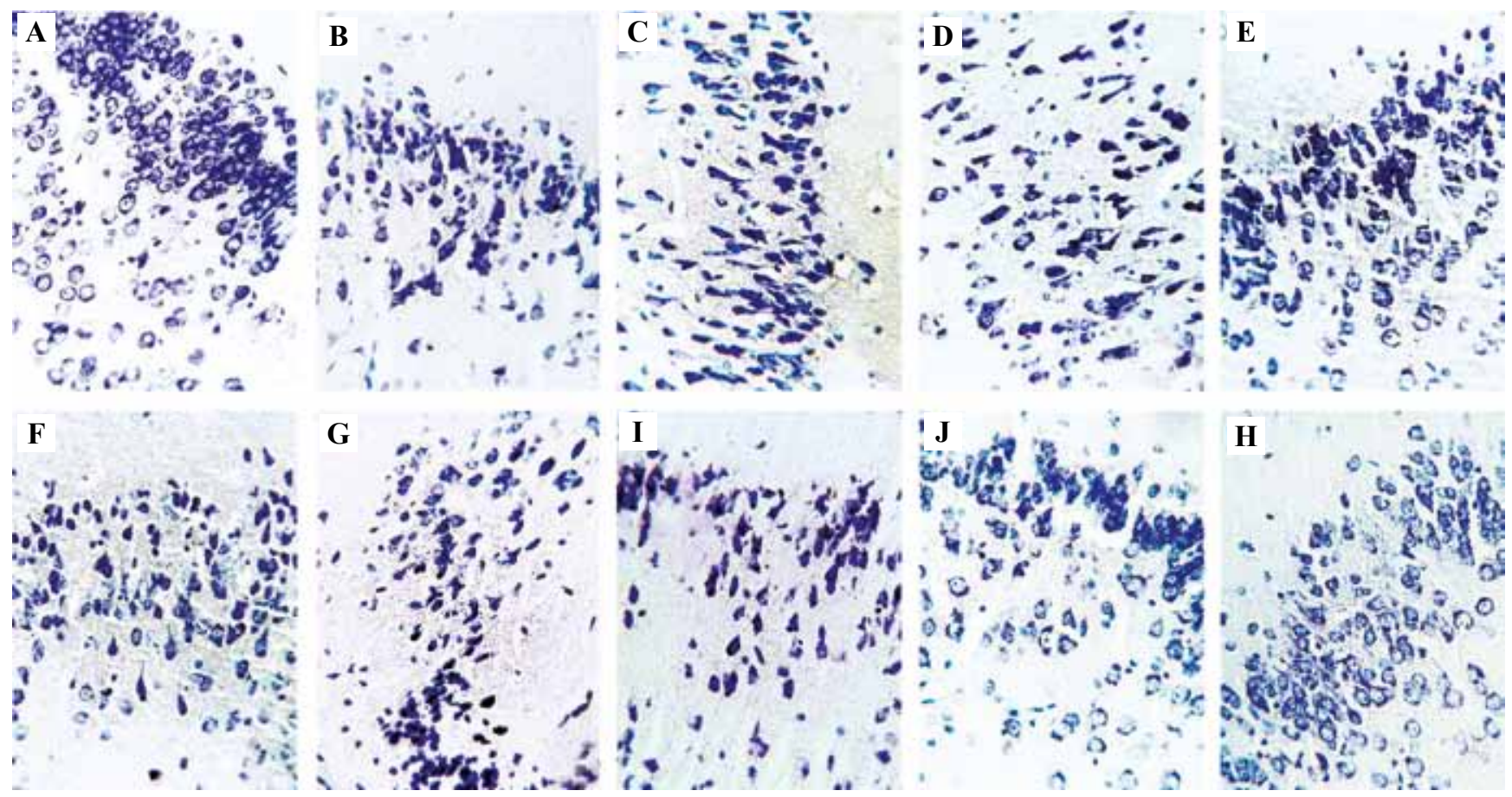

Fig. 3. Photomicrographs of the entorhinal cortex with Nissl stain $\times 400$.

A - intact; B - control animals treated with Corazol; C - animals treated with Corazol and SHD-89; D - animals treated with SHD-89; E - animals treated with Corazol and SHD-78; F - animals treated with SHD-78; G - animals treated with Corazol and SHD-91; H - animals treated with SHD-91; I - animals treated with Corazol and SHD-85; J - animals treated with SHD-85

Puc. 3. Микрофотографии энторинальной коры, окрашивание по Нисслю $\times 400$.

A - интактная группа, В - контрольные животные, получавшие коразол, С - животные, получавшие коразол и SHD-89, D - животные, получавшие SHD-89, E - животные, получавшие коразол и SHD-78, F - животные, получавшие SHD-78, $\mathrm{G}$ - животные, получавшие коразол и SHD-91, H - животные, получавшие SHD-91, I - животные, получавшие коразол и SHD-85, J - животные, получавшие SHD-85

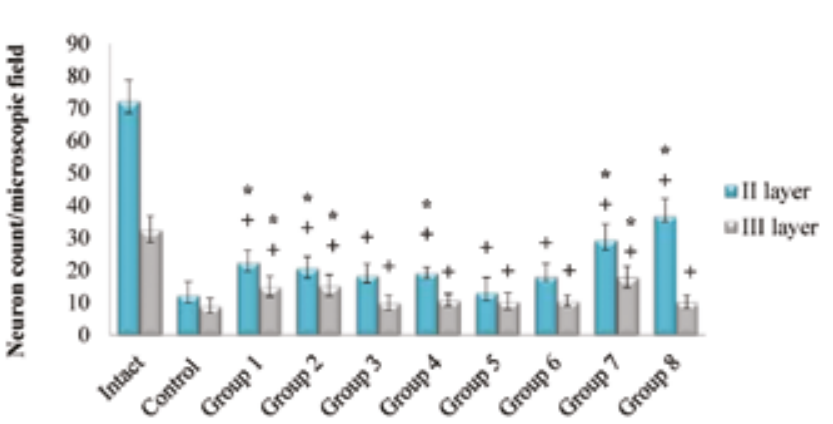

Fig. 4. The count of neuronal cells in the entorhinal cortex. Data are expressed as Mean $\pm \mathrm{SD} ; * \mathrm{p}<0.05$ compared to the control group; $+\mathrm{p}<0.05$ compared to the intact group

Puc. 4. Подсчет нейрональных клеток в энторинальной коре. Данные выражены как среднее \pm стандартное отклонение; * $\mathrm{p}<0,05$ по сравнению с контрольной группой; + $<<0,05$ по сравнению с интактной группой

reactive oxygen species, and neurotrophic factors that subsequently lead to neuronal damage and death $[35,36]$. Microglial cells, as well as astrocyte activation, are known to play an important role in epileptogenesis: experimental studies showed that after acute seizures or SE induced

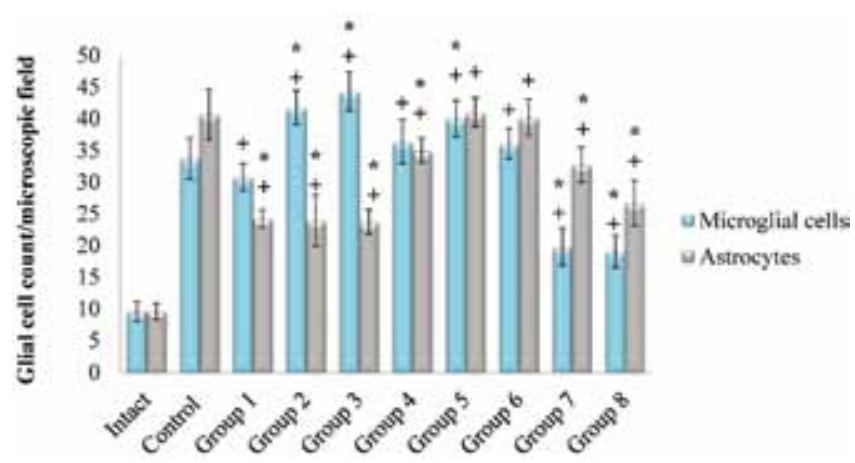

Fig. 5. The count of glial cells in the entorhinal cortex. Data are expressed as Mean $\pm \mathrm{SD} ; * \mathrm{p}<0.05$ compared to the control group; $+\mathrm{p}<0.05$ compared to the intact group

Puc. 5. Подсчет глиальных клеток энторинальной коры. Данные выражены как среднее \pm стандартное отклонение; * $\mathrm{p}<0,05$ по сравнению с контрольной группой; $+\mathrm{p}<0,05$ по сравнению с интактной группой

by convulsive drugs or electrostimulation, microglia were rapidly activated in various brain regions [37]. Activated microglia and astrocytes in seizures cause inflammation in brain tissue by releasing a number of proinflammatory mediators. Proinflammatory molecules can change neuronal 
excitability and affect the physiological functions of glia by paracrine or autocrine actions, thus perturbing the communication between glial cells and neurons [22, 38].

In the entorhinal cortex of control animals, there were prominent gliosis and neurolysis. In all layers, there were dark pyknotic neurons, as well as vacuolation and chromatolysis (Fig. 3B). In layer III, the number of pyramidal neurons drastically decreased and reached $9 \pm 2.36$ cells in the microscopic field. In layer II, the reduction was more prominent and the neuron count was $12.4 \pm 3.978$ cells (Fig. 4). Experimental studies on epilepsy, as well as those of the patients with TLE, demonstrated that there was a selective loss of neurons within layer III of the entorhinal cortex [39, 40], and this correlates with our findings. There was also hyperplasia of both microglial cells and astrocytes, the number of which was $33.7 \pm 3.23$ and $40.7 \pm 4$, respectively (Fig. 5).

In experimental group 1, there were prominent neurodegenerative processes in the entorhinal cortex. The number of neurons in layers II and III reduced and the count of neurons was $22.7 \pm 3.4$ and $15 \pm 3.09$, respectively. Although this number was significantly higher compared to that in the control animals $(p<0.05)$, it was significantly lower compared to that in the intact animals (Fig. 4). There were many dark pyknotic neurons along with chromatolytic neurons and active gliosis (Fig. 3C). The number of microglial cells was not significantly different from that of the control group ( $30.8 \pm 2.15$ cells), while the number of astrocytes was significantly lower compared to that of the control group [24.2 \pm 1.398$]$ (Fig. 5).

In experimental group 2, the results were similar. The number of neurons declined particularly in layer II. In layers II and III, the neurons were dark pyknotic (Fig. 3D), and their count was $20.9 \pm 3.24$ and $15.3 \pm 3.3$ cells, respectively (Fig. 4). In this group, there was also prominent microgliosis: the number of microglial cells was significantly higher compared to that of the control group (41.7 \pm 2.71 cells in the microscopic field). On the other hand, there were significantly fewer astrocytes than in the control animals [24 \pm 4.06 cells in the microscopic field] (Fig. 5).

Interestingly, under the effect of SHD-89 layer II of the cortex was more affected and showed pronounced microgliosis. We observed prominent epidural hematomas in the brains of animals treated with SHD-89 and Corazol. Simultaneously, in the brains of animals treated only with SHD-89, there was congestion of the vessels near the amygdala and pronounced gliosis of amygdala. This suggests that due to hemodynamic disbalance, neurons of layer II undergo hypoxic stress and ischemic necrosis as the dark cells; in this case, there was a pathological feature in these groups (Fig. 3C, D). Various experimental studies on traumatic brain injury demonstrated vascular disruption in acute stages of trauma to lead to the exhibition of abnormal dark neurons in the cortex and hippocampus [41].

In experimental group 3, layer II was characterized by a substantial decrease in the number of neurons that reached $18.5 \pm 3.47$ cells; the neurons were dark pyknotic (Fig. 3E). In layer III, the reduction in the number of neurons was substantial as well [ $10 \pm 2.36$ cells] (Fig. 4). Moreover, there was a prominent activation of the microglia. Compared to the number of microglial cells and astrocytes in the control group, here, that of the former was significantly higher $(44.3 \pm 3.06$ cells) and that of the latter was significantly lower [23.7 \pm 1.95 cells] (Fig. 5).

In the cortexes of animals from experimental group 4, we observed very similar morphological changes. There was a reduction in the number of neurons in layer III; layer II seemed to have pyknosis and pronounced gliosis (Fig. 3F). The number of neurons in layers II and III was $19.4 \pm 1.51$ and $10.8 \pm 1.93$, respectively (Fig. 4). Gliosis was also pronounced: the number of microglial cells was $36.4 \pm 3.44$ and that of astrocytes ( $35 \pm 2$ cells) was higher in this group compared to experimental groups 1,2 , and 3 (Fig. 5). The presence of dark pyknotic neurons in experimental groups 3 and 4 treated with compound SHD-78 can also be a result of hemodynamic changes and congestion.

In experimental group 5, there were severe pathological changes in the entorhinal cortex: pronounced chromatolysis and pyknosis of neurons, as well as multiple foci of microgliosis (Fig. 3G). In layer II, the reduction in the number of neurons was significant and amounted to $13.3 \pm 4.47$ cells in the microscopic field, whereas in layer III, the number of pyramidal cells was $10.5 \pm 2.593$ (Fig. 4). Because of gliosis and brain swelling the neurons of layer II traveled to layer I. The numbers of microglial cells and astrocytes were elevated compared to that in other groups [ $40 \pm 2.83$ and $41 \pm 2.26$, respectively] (Fig. 5).

Without Corazol, SHD-91 produces mild pathological changes in the entorhinal cortex of mice. There was a reduction in the number of neurons in layers II and III [18.2 \pm 3.99 and $10.6 \pm 1.713$ cells, respectively] (Fig. 4). We observed substantial neuronal necrosis and pyknosis, as well as microgliosis in all layers (Fig. 3H). Glial cell count showed that in this group, the numbers of microglial cells and astrocytes increased to $36.1 \pm 2.38$ and $40.2 \pm 2.86$, respectively. The number of glial cells was not significantly different from that in the control group (Fig. 5).

In experimental groups 5 and 6 , the neurodegenerative processes in the brain tissue were more pronounced than in other groups. Pathological changes of the brain tissue were particularly noticeable in group 5: there were structural changes in the hippocampus and entorhinal cortex. This suggests that SHD-91 has a synergic effect on Corazol that, in turn, leads to the activation of astrocytes and changes the structure of the brain in mice. Numerous experimental studies on epilepsy demonstrate that prior to seizures there are morphological changes in both astrocytes and neurons in the brain. Palisading astrocytes immediately surround the injury site, and their processes form a halo around the lesion with striking radial orientation [42]. This phenomenon was observed in experimental groups 5 and 6 where there was pronounced astrogliosis in the hippocampal region and entorhinal cortex.

In experimental group 7, the morphological picture of the cortex was almost the same as in the intact animals 
(Fig. 3I). Although in layer II, the number of neuronal cells reduced $(29.6 \pm 4.65$ cells $)$, it was significantly higher compared to that in the control and experimental groups 1-6. In layer III, the number of pyramidal cells was the highest of all experimental groups [17.9 \pm 3.381 cells in the microscopic field] (Fig. 4). There was a lower activation of microglia than in other groups. The count of microglial cells was $19.8 \pm 2.94$, which is significantly lower compared to that in the control animals. Although the number of astrocytes was slightly higher ( $32.8 \pm 2.78$ cells), it was significantly lower than in the control group (Fig. 5). Overall, pathological processes were moderate in comparison with other experimental groups.

In experimental group 8, however, we observed a reduction in the number of nerve cells in the entorhinal cortex to be more considerable, especially in layer III $(10.3 \pm 2.06$ cells $)$. In layer II, on the other hand, the neurons were more preserved (Fig. 3J), and their number was the highest in this group compared to that in other experimental groups [37 \pm 5.099 cells] (Fig. 4). Gliosis was moderate as well: the number of microglial cells was much lower compared to that in the control and other experimental groups $(19.1 \pm 2.51$ cells $)$. Astrocytes count was significantly lower compared to that in the control animals $[26.7 \pm 3.56$ cells] (Fig. 5).

The reduction in the number of neurons in layer III suggests that although SHD- 85 has almost no pathological effect on the hippocampus, it affects the entorhinal cortex leading to neuronal loss in this region. This phenomenon should be studied further with different doses of SHD-85.

\section{Conclusion}

Histological and pathological studies of brain tissue under the effects of new derivatives of pyrazolyl-thienopyridines with and without chemoconvulsant agent Corazol show that among all the studied compounds SHD-78 and SHD-89 cause moderate morphological changes to the hippocampus and entorhinal cortex, whereas compound SHD-91 produces severe neurodegenerative effects on brain tissue. Moreover, SHD-85 shows neuroprotective activity with reducing gliosis and neuronal loss induced by Corazol.

\footnotetext{
Author contributions

Conceived the study and designed the experiment - H.V. Gasparyan, R.G. Paronikyan, I.M. Nazaryan.

Synthesis of chemical compounds - Sh.Sh. Dashyan, E.G. Paronikyan. Collected the data and performed the analysis - H.V. Gasparyan, S.A. Buloyan, A.E. Pogosyan, L.M. Arshakyan, L.S. Harutyunyan. Wrote the paper-S.A. Buloyan.

Edited the manuscript - H.V. Gasparyan, S.A. Buloyan.

\section{Вклад авторов}

Концепция и дизайн исследования - Г.В. Гаспарян, Р.Г. Пароникян, И.М. Назарян.

Синтез химических соединений - Ш.Ш. Дашян, Е.Г. Пароникян. Сбор и обработка материала - Г.В. Гаспарян, С.А. Булоян,

А.Е. Погосян, Л.М. Аршакян, Л.С. Арутюнян.

Написание текста - С.А. Булоян.

Редактирование - Г.В. Гаспарян, С.А. Булоян.
}

\section{References/Литература}

1. Stafstrom CE, Carmant L. Seizures and epilepsy: An overview for neuroscientists. Cold Spring Harb Perspect Med. 2015;5(6):a022426. DOI: 10.1101/cshperspect.a022426.

2. Chang BS, Lowenstein DH. Epilepsy. N Engl J Med. 2003; 349(13):1257-66. DOI: 10.1056/NEJMra022308.

3. de Lanerolle NC, Lee TS, Spencer DD. Histopathology of human epilepsy. In: JL Noebels, M Avoli, MA Rogawski, RW Olsen, AV Delgado-Escueta (eds.). Jasper's Basic Mechanisms of the Epilepsies. 4th ed. Bethesda (MD): National Center for Biotechnology Information (US), 2012. P. 567-595. PMID: 22787669.

4. Steward O, Torre ER, Tomasulo R, Lothman E. Seizures and the regulation of astroglial gene expression. Epilepsy Res Suppl. 1992;7:197-209. PMID: 1334663.

5. Yilmazer-Hanke DM, Wolf HK, Schramm J, Elger CE, Wiestler $O D$, Blümcke I. Subregional pathology of the amygdala complex and entorhinal region in surgical specimens from patients with pharmacoresistant temporal lobe epilepsy. J Neuropathol Exp Neurol. 2000;59(10):907-20. DOI: 10.1093/jnen/59.10.907.

6. Cendes F, Andermann F, Dubeau F, Gloor P, Evans A, Jones-Gotman $M$ et al. Early childhood prolonged febrile convulsions, atrophy and sclerosis of mesial structures, and temporal lobe epilepsy. Neurology.1993;43(6):1083-7. DOI: 10.1212/wn1.43.6.1083.

7. Zhang Z, Sun T, Niu JG, He ZQ, Liu Y, Wang F. Amentoflavone protects hippocampal neurons: Anti-inflammatory, antioxidative, and antiapoptotic effects. Neural Regen Res. 2015;10(7):1125-33. DOI: $10.4103 / 1673-5374.160109$.

8. Rho JM, White HS. Brief history of anti-seizure drug development. Epilepsia Open. 2018;3(SupplSuppl 2):114-9. DOI: 10.1002/epi4.12268.

9. Bhattacharya SK, Ghosal S, Chaudhuri RK, Singh AK, Sharma PV. Letter: Chemical constituents of gentianaceae. XI. Antipsychotic activity of gentianine. J Pharm Sci. 1974;63(8):1341-2. DOI: $10.1002 /$ jps.2600630850.

10. Yu S, Huang $Q Q$, Luo $Y, L u W$. Total synthesis of camptothecin and SN-38. J Org Chem. 2012;77(1):713-7. DOI: 10.1021/ jo201974f.

11. Wei SH, Jiang ZH, Tian SH, Zhang D. Highly facile approach to the formal total synthesis of camptothecin. Tetrahedron Lett. 2013;54(34):4515-7. DOI: 10.1016/j.tetlet.2013.06.057.

12. El-Sayed Ali T. Synthesis of some novel pyrazolo[3,4-b]pyridine and pyrazolo[3,4-d]pyrimidine derivatives bearing 5,6-diphenyl-1,2,4-triazine moiety as potential antimicrobial agents. Eur J Med Chem. 2009;44(11):4385-92. DOI: 10.1016/j.ejmech.2009.05.031.

13. Salem MS, Ali MA. Novel pyrazolo[3,4-b]pyridine derivatives: Synthesis, characterization, antimicrobial and antiproliferative profile. Biol Pharm Bull. 2016;39(4):473-83. DOI: 10.1248/bpb. b15-00586.

14. Bernardino AMR, de Azevedo ARG, Pinheiro LCDS, Borges JC, de Carvalho VL, Miranda MD et al. Syntehsis and antiviral activity of new 4-(phenylamino)/4-[(methylpidin-2-yl) amino]1-phenyl-1H-pyrazolo-[3,4-b]-pyridine-4-carboxylic acid derivatives. Med Chem Res. 2007;16(7):352-69. DOI: 10.1007/ s00044-007-9035-6.

15. de Mello H, Echevarria A, Bernardino AM, Canto-Cavalheiro M, Leon LL.Antileishmanialpyrazolopyridine derivatives: Synthe- 
sis and structure-activity relationship analysis. J Med Chem. 2004;47(22);5427-32. DOI: 10.1021/jm0401006.

16. Hamdy NA, Gamal-Eldeen AM. New pyridone, thioxopyridine, pyrazolopyridine and pyridine derivatives that modulate inflammatory mediators in stimulated RAW 264.7 murine macrophage. Eur J Med Chem. 2009;44(11):4547-56. DOI: 10.1016/j. ejmech.2009.06.023.

17. Jordão AK, Ferreira VF, Lima ES, de Souza MC, Carlos EC, Castro HC et al. Synthesis, antiplatelet and in silico evaluations of novel N-substituted-phenylamino-5-methyl-1H-1,2,3-triazole4-carbohydrazides. Bioorg Med Chem. 2009;17(10):3713-9. DOI: 10.1016/j.bmc.2009.03.053.

18. Kasabov KA, Kudryashov NV, Volkova AV, Shimshirt AA, Kalinina TS, Zhmurenko LA et al. Psychotropic effects of a new pyrazolo[C]pyridine derivate GIZh-72 are related to functional activity of atp-sensitive potassium channels. Bull Exp Biol Med. 2020;168(4):449-52. DOI: 10.1007/s10517-020-04729-5.

19. Paronikyan EG, Petrou A, Fesatidou M, Geronikaki A, Dashyan SS, Mamyan SS et al. Derivatives of a new heterocyclic system-pyrano[3,4-c][1,2,4]triazolo[4,3-a]pyridines: Synthesis, docking analysis and neurotropic activity. Medchemcomm. 2019;10(8):1399-411. DOI: 10.1039/c9md00187e.

20. Dabaeva VV, Bagdasaryan MR, Dashyan SS, Dzhagatspanyan IA, Nazaryan IM, Akopyan AG et al. Synthesis and neurotropic activity of new condensed pyrano[4,3-b]-pyridines derivatives. Pharm Chem J. 2019;52(3):844-9. DOI: 10.1007/ s11094-019-1912-z.

21. do Nascimento AL, Dos Santos NF, Campos Pelágio F, Aparecida Teixeira S, de Moraes Ferrari EA, Langone F. Neuronal degeneration and gliosis time-course in the mouse hippocampal formation after pilocarpine-induced status epilepticus. Brain Res. 2012;1470:98-110. DOI: 10.1016/j.brainres.2012.06.008.

22. Zheng Y, Moussally J, Cash SS, Karnam HB, Cole AJ. Intravenous levetiracetam in the rat pilocarpine-induced status epilepticus model: Behavioral, physiological and histological studies. Neuropharmacology. 2010;58(4-5):793-8. DOI: 10.1016/j.neuropharm.2009.12.007.

23. Dalby NO, Mody I. The process of epileptogenesis: A pathophysiological approach. Curr Opin Neurol. 2001;14(2):187-92. DOI: 10.1097/00019052-200104000-00009.

24. Gualtieri F, Curia G, Marinelli C, Biagini G. Increased perivascular laminin predicts damage to astrocytes in CA3 and piriform cortex following chemoconvulsive treatments. Neuroscience. 2012;218:278-94. DOI: 10.1016/j.neuroscience.2012.05.018.

25. Karpova MN, Vetrile LA, Klishina NY, Trekova NA, Kuznetsova $L V$, Evseev $V A$. Elevation of corazol-induced seizure threshold after active immunization of mice of various genetic strains with glutamate-bovine serum albumin conjugate. Bull Exp Biol Med. 2003;136(3):250-2. DOI: 10.1023/b:bebm.0000008975. 89978.0f.

26. Mathern GW, Babb TL, Armstrong DL. Hippocampal sclerosis. In: J Engel, TA Pedley (eds.). Epilepsy: A Comprehensive Textbook. Philadelphia: Lippincott-Raven. 1997. P. 133-155.

27. Chang CS, Liao CH, Lin CC, Lane HY, Sung FC, Kao CH. Patients with epilepsy are at an increased risk of subsequent stroke: A population-based cohort study. Seizure. 2014;23(5):377-81. DOI: $10.1016 /$ j.seizure.2014.02.007.
28. Curia G, Lucchi C, Vinet J, Gualtieri F, Marinelli C, Torsello A et al. Pathophysiogenesis of mesial temporal lobe epilepsy: Is prevention of damage antiepileptogenic? Curr Med Chem. 2014;21(6): 663-88. DOI: 10.2174/0929867320666131119152201.

29. Jacinto LR, Mata R, Novais A, Marques F, Sousa N. The habenula as a critical node in chronic stress-related anxiety. Exp Neurol. 2017;289:46-54. DOI: 10.1016/j.expneurol.2016.12.003.

30. Zhang SJ, Ye J, Couey JJ, Witter M, Moser EI, Moser MB. Functional connectivity of the entorhinal-hippocampal space circuit. Philos Trans R SocLond B Biol Sci. 2013;369(1635):20120516. DOI: $10.1098 /$ rstb.2012.0516.

31. Ibrahim KR, Hala ZEM. Histological changes of the adult albino ratsentorhinal cortex under the effect of tramadol administration: Histological and morphometric study. Alexandria Journal of Medicine. 2016;53(2):123-33. DOI: 10.1016/j.ajme.2016.05.001.

32. Bartolomei F, Khalil M, Wendling F, Sontheimer A, Régis J, Ranjeva JP et al. Entorhinal cortex involvement in human mesial temporal lobe epilepsy: an electrophysiologic and volumetric study. Epilepsia. 2005;46(5):677-87. DOI: 10.1111/j.15281167.2005.43804.x.

33. Dolorfo CL, Amaral DG. Entorhinal cortex of the rat: Topographic organization of the cells of origin of the perforant path projection to the dentate gyrus. J Comp Neurol. 1998;398(1): 25-48. PMID: 9703026.

34. van Groen T, Miettinen P, Kadish I. The entorhinal cortex of the mouse: Organization of the projection to the hippocampal formation. Hippocampus. 2003;13(1):133-49. DOI: 10.1002/ hipo. 10037.

35. Bak LK, Schousboe A, Waagepetersen HS. The glutamate/GABAglutamine cycle: Aspects of transport, neurotransmitter homeostasis and ammonia transfer. J Neurochem. 2006;98(3):641-53. DOI:10.1111/j.1471-4159.2006.03913.x

36. Goswami P, Gupta S, Joshi N, Sharma S, Singh S. Astrocyte activation and neurotoxicity: A study in different rat brainregions and in rat C6 astroglial cells. Environ Toxicol Pharmacol. 2015;40(1):122-39. DOI: 10.1016/j.etap.2015.06.001.

37. Hiragi T, Ikegaya Y, Koyama R. Microglia after seizures and in epilepsy. Cells. 2018;7(4):26. DOI: 10.3390/cells7040026.

38. Vezzani A, Aronica E, Mazarati A, Pittman QJ. Epilepsy and brain inflammation. Exp Neurol. 2013;244:11-21. DOI: 10.1016/j. expneurol.2011.09.033.

39. Drexel M, Preidt AP, Sperk G. Sequel of spontaneous seizures after kainic acid-induced status epilepticus and associated neuropathological changes in the subiculum and entorhinal cortex. Neuropharmacology. 2012;63(5):806-17. DOI: 10.1016/j.neuropharm.2012.06.009.

40. Vismer MS, Forcelli PA, Skopin MD, Gale K, Koubeissi MZ.The piriform, perirhinal, and entorhinal cortex in seizure generation. Front Neural Circuits. 2015;9:27. DOI: 10.3389/fncir.2015.00027.

41. Cortez SC, McIntosh TK, Noble LJ. Experimental fluid percussion brain injury: Vascular disruption and neuronal and glial alterations. Brain Res. 1989;482(2):271-82. DOI: 10.1016/00068993(89)91190-6.

42. Oberheim NA, Tian GF, Han X, Peng W, Takano T, Ransom B, Nedergaard $M$. Loss of astrocytic domain organization in the epileptic brain. J Neurosci. 2008;28(13):3264-76. DOI: 10.1523/ JNEUROSCI.4980-07.2008. 


\section{Author information}

Hrachik V .Gasparyan - Cand. Sci. (Biol.), Head of the Laboratory of Pharmacology and Histopathology, Scientific Technological Center of Organic and Pharmaceutical Chemistry National Academy of Sciences of the Republic of Armenia https://orcid.org/0000-0002-8555-3733

Sona A. Buloyan - Cand. Sci. (Biol.), Researcher, Laboratory of Pharmacology and Histopathology, Group of Histopathology, Scientific Technological Center of Organic and Pharmaceutical Chemistry National Academy of Sciences of the Republic of Armenia. https://orcid.org/0000-0002-6739-509X

Anahit E. Pogosyan - Researcher, Laboratory of Pharmacology and Histopathology, Group of Histopathology, Scientific Technological Center of Organic and Pharmaceutical Chemistry National Academy of Sciences of the Republic of Armenia.

https://orcid.org/0000-0001-8776-1483

Lilit M. Arshakyan - Junior Researcher, Laboratory of Pharmacology and Histopathology, Group of Cytology and Biochemistry, Scientific Technological Center of Organic and Pharmaceutical Chemistry National Academy of Sciences of the Republic of Armenia. https://orcid.org/0000-0002-1486-5457

Lusine S. Harutyunyan - Laboratory Assistant, Laboratory of Pharmacology and Histopathology, Group of Cytology and Biochemistry, Scientific Technological Center of Organic and Pharmaceutical Chemistry National Academy of Sciences of the Republic of Armenia. https://orcid.org/0000-0001-8360-9070

Ruzanna G. Paronikyan - Cand. Sci. (Biol.), Researcher, Laboratory of Pharmacology and Histopathology, Group of Studies of Anticonvulsant and Psychotropic Compounds, Scientific Technological Center of Organic and Pharmaceutical Chemistry National Academy of Sciences of the Republic of Armenia

https://orcid.org/0000-0002-3845-6324

Ivetta M. Nazaryan - Researcher, Laboratory of Pharmacology and Histopathology, Group of Studies of Anticonvulsant and Psychotropic Compounds, Scientific Technological Center of Organic and Pharmaceutical Chemistry National Academy of Sciences of the Republic of Armenia.

https://orcid.org/0000-0003-2531-8093

Shushan Sh. Dashyan - Cand. Sci. (Chem.), Researcher, Laboratory of the Synthesis of Psychotropic Compounds, Scientific Technological Center of Organic and Pharmaceutical Chemistry National Academy of Sciences of the Republic of Armenia. https://orcid.org/0000-0002-6365-3725

Ervand G. Paronikyan - Dr. Sci. (Chem.), Head of Laboratory of the Synthesis of Psychotropic Compounds, Scientific Technological Center of Organic and Pharmaceutical Chemistry National Academy of Sciences of the Republic of Armenia. https://orcid.org/0000-0002-6048-3599

\section{Информация об авторах}

Грачик Ваграмович Гаспарян - кандидат биологических наук, заведующий лабораторией фармакологии и гистопатологии Научнотехнологического Центра органической и фармацевтической химии Национальной академии наук Республики Армения.

Сона Азатовна Булоян - кандидат биологических наук, научный сотрудник, лаборатория фармакологии и гистопатологии, группа гистопатологии Научно-технологического Центра органической и фармацевтической химии Национальной академии наук Республики Армения.

Анаит Ервандовна Погосян - научный сотрудник, лаборатория фармакологии и гистопатологии, группа гистопатологии Научнотехнологического Центра органической и фармацевтической химии Национальной академии наук Республики Армения.

Лилит Мартиновна Аршакян - младший научный сотрудник, лаборатория фармакологии и гистопатологии, группа цитологических и биохимических исследований Научно-технологического Центра органической и фармацевтической химии Национальной академии наук Республики Армения.

Лусине Саргисовна Арутюнян - лаборант лаборатории фармакологии и гистопатологии, группа цитологических и биохимических исследований Научно-технологического Центра органической и фармацевтической химии Национальной академии наук Республики Армения

Рузанна Гарниковна Пароникян - кандидат биологических наук, старший научный сотрудник, лаборатория фармакологии и гистопатологии, группа исследований противосудорожных и психотропных веществ Научно-технологического Центра органической и фармацевтической химии Национальной академии наук Республики Армения.

Иветта Маратовна Назарян - научный сотрудник, лаборатория фармакологии и гистопатологии, группа исследований противосудорожных и психотропных веществ Научно-технологического Центра органической и фармацевтической химии Национальной академии наук Республики Армения.

Шушан Шамировна Дашян - кандидат химических наук, научный сотрудник, лаборатория синтеза психотропных соединений Научно-технологического Центра органической и фармацевтической химии Национальной академии наук Республики Армения. Ерванд Гарникович Пароникян - доктор химических наук, заведующий лабораторией синтеза психотропных соединений Научно-технологического Центра органической и фармацевтической химии Национальной академии наук Республики Армения. 